\title{
The investigation of pancreatic function in pancreatitis
}

\author{
Oliver FitzGerald \\ M.D., M.Sc.
}

St Vincent's Hospital and Department of Medicine and Therapeutics, University College, Dublin

\section{Introduction}

In the past decade there has been a considerable expansion in the number of pancreatic function tests. There has also been a considerable improvement in their precision, reliability and reproducibility. The pancreas is often thought of as only commonly subject to one disease-diabetes. It would appear to be unlikely that so large and so continually active a gland should not exhibit fairly frequently other serious disorders ranging from the inflammatory to the malignant. That all these possibilities occur is accepted but the statistical probability of a high incidence of occult pancreatic disease is not yet accepted. This may be in part due to the social stigma attached to chronic pancreatitis so long thought to be, like hepatic cirrhosis, of alcoholic origin. In truth chronic pancreatitis has a currently accepted alcoholic association in the United States of something like $30 \%$. We think that the true association is less than $10 \%$, taking all cases of pancreatitis into account.

We will try to deal with the various procedures suitable for the diagnosis of acute or chronic pancreatitis. The simplest way to deal with the problem is that of describing the various tests which can be used in theory of use, the most suitable form of that test to use, and general suitability. This has at times required consideration not alone of the theoretical basis for the test, but also of the theoretical optima for the analytical techniques used. Finally, we have endeavoured to give a brief account of the common faults or errors, either physiological or technical, which might vitiate the value of a test.

We must confess to a preference for a specific or direct test rather than an indirect one. The use of batteries of tests or test profiles can be occasionally valuable provided we are prepared to recognize the various salient points from the mass effect of the total battery. Many tests in this field are suitable only for an advanced case associated with consider-

*The material in this article is abridged from a monograph on Pancreatitis by $\mathbf{O}$. FitzGerald, P. FitzGerald and J. P. McMullin, to be published shortly by William Heinemann Medical Books, London, and by Charles C. Thomas, Fort Lauderdale, Florida. able pancreatic damage and will be quite normal in an early case which might be curable when diagnosed by a specific test. Alternatively, many of these tests are really to evaluate the degree of disturbance, the diagnosis having already been made.

The tests having been described, we would propose to indicate how they can be applied to the diagnosis of the individual disorders referred to above. This will not require much space but is, of course, the primary purpose of the review.

\section{Tests involving studies of pancreatic secretory capacity}

This has been studied for a considerable time. Serum amylase determinations in the diagnosis of acute pancreatitis were amongst the first serum enzymes regularly studied, having been introduced as a clinical procedure by Elman \& McGoughan (1927). Since then there has been much effort expended to increase the sophistication of laboratory techniques involved, to expand the number of enzymes which can be studied, or to introduce new methods of pancreatic stimulation either direct, such as the use of secretin, or indirect such as the digestive technique of Lundh. There have been many advances but some curious retrogressions could be recorded. It is certain that we can firmly diagnose pancreatic disease on many more occasions now than formerly. This should not be taken as claiming that all cases can be diagnosed at the first encounter though far more could be than is recognized by some clinicians. We will describe the acceptable methods of study in terms of suitability of enzyme technique, fluids studied and their source.

\section{Enzymes}

\section{Amylase in biological fluids}

(a) The problem can be recognized and quantitatively estimated by many methods usually variants of two aspects of the action of this enzyme, either amyloclasis (i.e. breakdown of starch) as recognized in terms of disappearance of the starch iodine reaction, or of saccharogenesis (the appearance of sugar), or of such side effects of the enzyme's action as decreased viscosity of a starch solution. An amyloclastic technique such as that of Somogyi 
has been widely used but it is no longer really acceptable for accurate work nor will it bear those refinements which have been imposed on it such as electrophoretic partition of possible iso-amylases. Iso-enzymes were thought to be present in the circulating serum, accompanied by inhibitors to a varying degree depending upon the form of pancreatic disease present (Dreiling, Janowitz \& Josephberg, 1963). The amylase technique involved was an amyloclastic one.

A considerable amount of amylase appeared also to be attached to the albumin and to the $\gamma$-globulin fraction of serum. This suggested the occasional presence of at least two iso-enzymes in the serum. The Albumin only mimics amyloclasis for, when the albumin-bound fraction was boiled, it still had, unlike similarly treated $\gamma$-globulin fraction, considerable amyloclastic activity indicating that the amyloclasis was non-enzymatic (Berk et al., 1964). The effect may be due to release of free -SH groups (R. A. Q. O'Meara, 1966, personal communication). The albumin-bound fraction showed no saccharogenic activity at any time. That there are isoamylases, notably of hepatic or salivary origin, seems highly probable (McGeachin \& Reynolds, 1959). Recently evidence has been advanced that, at least in the case of acute pancreatitis, some fraction of the circulating amylase is more sensitive to such procedures as prolonged electrophoresis (possibly owing to the heat involved) than is serum from normal patients (Hayashi et al., 1966). An earlier study had indicated that, if normal sera were partitioned and the amylase activity of the fractions were separately determined by an amyloclastic method and summed, the total activity could be treble that of the whole serum's amyloclastic activity (Dreiling et al., 1963). If serum from patients with acute pancreatitis were studied, no such disparity was found. This observation led to the conclusion that normal serum contains an amylase inhibitor separated from the enzyme at electrophoresis but that the serum from a case of acute pancreatitis did not contain normal amounts of the inhibitor. This conclusion is no longer accepted, though it may be that in acute pancreatitis a globulin-bound iso-enzyme (more sensitive to heat than is the normal enzyme) is present. Circulating amylase inhibitors may be present, but their presence has not been proven.

(b) Technique. There is no doubt that the method of choice for amylase determination must be saccharogenic. The oldest technique available is again that of Somogyi (1938) which has been modified by a number of workers because it is basically inadequately buffered. This has often involved undue reduction of starch content as well (Young, 1953). A recent modification requires only $30 \mathrm{~min}$ incubation but the resultant figures cannot be expressed in international units. One unit equals $1 \mu$ mole of maltose $(0.36 \mathrm{mg}$ maltose monohydrate) released per minute. There are thus a number of objections (all of them not enumerated here) to Somogyi's method or most of its modifications. We have up to recently (FitzGerald et al., 1963) used the method of Myers, Free \& Rosinski (1944) in which the reaction is stopped with picric acid and the sugar produced estimated by a copper reduction technique. It has been satisfactory in our hands but labours from the disadvantage that the unspecified starch ordinarily used is only sparingly soluble and this may affect amylase determinations when using different batches of starch. It also makes comparison of results between one laboratory and another difficult, precise unitage is not possible and the method is rather slow. We have (Carey, FitzGerald \& McGeeney, 1967a) recently adapted the method of Ujihira et al. (1965). It requires only $15 \mathrm{~min}$ incubation, pathological variations of serum constituents (apart from blood sugar $>500 \mathrm{mg} / 100$ $\mathrm{ml})$ do not interfere, it is sensitive and the conversion to units is easy.

The method is as follows:

Procedure. A $10 \mathrm{ml}$ graduated centrifuge tube containing $0.2 \mathrm{ml}$ of serum is placed in a water-bath at $37 \pm 0 \cdot 1^{\circ}$ for 5-6 min to reach the temperature of the bath. A sufficient amount of Zulkowsky? starch solution is at the same time placed in another test-tube in the water-bath. Then $0.5 \mathrm{ml}$ of the substrate solution is transferred to the tube containing the serum, the solutions are mixed and at the same time a stop-watch is started. After exactly $15 \mathrm{~min}$ of incubation the enzymatic reaction is interrupted by the addition of $1 \mathrm{ml}$ of the 3:5dinitrosalicylate reagent.

A zero-time sample with the same composition is prepared in another test tube but in this tube the 3-5-dinitrosalicylate reagent is added before the starch solution after $15 \mathrm{~min}$.

The tubes are immersed in a vigorously boiling water-bath for $5 \mathrm{~min}$ and then chilled in iced water. Each is then made up with distilled water to the $10 \mathrm{ml}$ mark and shaken vigorously. The tubes are then centrifuged at speed ' 5 ' on a christ bench centrifuge. The intensity of the red colour is measured in a spectrophotometer at $530 \mathrm{~m} \mu$ in $1-\mathrm{cm}$ cuvettes. The colour is stable for at least $24 \mathrm{hr}$. The amount of reducing groups liberated, i.e. the difference between the incubated sample and the zero-time sample, expressed as milligrams of maltose monohydrate, is obtained from a standard curve.

What fluids can be studied for amylase activity? Provided that the incubation circumstances are correct, that there is no remarkable excess of sugar 
and that (in the case of older methods) there is no haemolysis, all body fluids can be examined, i.e. serum, urine, pleural, pericardial and peritoneal.

(c) Faults and sources of error of amylase determination. (1) Errors in physiological assumption. The pancreas is not the only source of amylase. This is true even of normal serum or urine in which amylase both of hepatic, salivary and pancreatic origin may be found. In the normal person there are at least two urinary iso-amylases, one of salivary the other of pancreatic origin. The Fallopian tube may be the source of the increased levels of serum amylase in menstruation (Carey et al., 1966a) as also following rupture of a tubal pregnancy. Similarly in pregnancy there is a steady rise in the later months (FitzGerald, 1965). Amylase is normally excreted through the kidney by glomerular filtration. There is some delay, so that levels of serum and urinary amylase do not necessarily run in parallel. In conditions of decreased glomerular filtration such as the shock syndrome or chronic renal failure high serum levels may result. This may in part explain the increased serum amylase levels in cases of perforated peptic ulcer or other abdominal catastrophes. Opiates such as morphine which cause sphincteric spasm may also lead to hyperamylasaemia. Hypergammaglobulinaemia may also lead to increased amylase binding and thus increased serum levels (Wilding, Cooke \& Nicholson, 1964).

(2) Technical faults or faulty assumptions. We have dealt with most of those difficulties in the earlier part of this section but feel that they can be summarized. Many methods suitable for urine or duodenal juice are too insensitive for serum yet are not infrequently used. Many methods do not define the starch to be used or use it in an unbuffered medium. Comparison of results from one laboratory to another or even inside the same laboratory on different days is important and dependent upon well-defined technical arrangements which can be reduced to a single standard or unit. This was not possible with many older methods but we think that it is all realizable with a more modern technique such as that described above.

\section{Lipase in biological fluids}

(a) The term 'lipase' can be used in a limited or in a wide sense. Used in the latter sense it means an enzyme capable of breaking down fatty acid esters with long C-chains or of hydrolysing esters of glycerol, chiefly triglycerides, or hydrolysing esters in heterogeneous systems (Sarda \& Desnuelle, 1958) It is thus, as used in this wide sense, an esterase. However, by clinical laboratory usage the term 'lipase' would be reserved for an enzyme which (like pancreatic lipase) attacks lipid emulsions in a heterogeneous system whereas esterases hydrolyse dissolved fatty acid esters in a homogeneous system. Pancreatic lipase is a unique enzyme in clinical enzymology as it acts at the oil-water interface. All this may appear academic but methods of determining lipase activity using relatively short-chain fatty acid esters have been proposed and are by this definition unsuitable. Other enzymes breaking down fatty acids esters such as may be derived from the liver are not lipases but esterases. The two requirements for the substrate of a lipase are: (i) that it be a long chain triglyceride, and (ii) that it be in a highly dispersed emulsion at suitable $\mathrm{pH}$. The addition of a suitable stabilizer after primary emulsification may be necessary, but some stabilizers could interfere with lipase activity. It may be difficult to compare figures from one laboratory with those of another. Two further extra factors may be referred to. Lipase activity falls off rapidly in vitro at $37^{\circ}$ being reduced by $30 \%$ at $30 \mathrm{~min}$. Therefore the shorter the incubation time the better. Many older techniques such as that of Cherry \& Crandall (1932) required $24 \mathrm{hr}$ incubation, Tietz, Borden \& Stepleton's (1959) modification of it $6 \mathrm{hr}$ and a later modification of Tietz $4 \mathrm{hr}$ (Weber, 1965). The second point is that pancreatic lipase attacks the attachment of the fatty acid to the two primary $\left(\alpha-\alpha_{1}\right) \mathrm{OH}$ groups of the molecule, leaving behind a monoglyceride from which the fatty acid may shift to one of these $\mathrm{OH}$ groups again with renewed possibility of attack. There is reason for ensuring as rapid an interaction between lipase and triglyceride as possible. This zero-order kinetics may be approached though, obviously, not entirely achieved.

(b) Technique. The requirements for an ideal method of lipase determination have been expressed and it will be realized that many commonly used methods are subject to major disadvantages. We have long used the method of Cherry \& Crandall (1932) with minor modifications notably perhaps in the type of olive oil emulsion used. We have not used any of the modifications such as that of Tietz referred to above but it can readily be seen that both of these methods are open to criticisms. We have never been entirely satisfied with the Cherry \& Crandall technique apart from these criticisms, owing to the difficulty of reproducibility of results from one laboratory to another and also due to occasional contradictable variations in lipase values which had not, in our experience, been sufficiently often in parallel with amylase figures themselves more consonant with clinical findings. Hence the anxiety for a new method which we have recently developed (Carey et al., 1967b). This method is quite new and is entirely suitable for all biological fluids except possibly urine, owing to the presence of an inhibitor in that fluid. It is quick, sensitive, specific for lipase and inexpensive. It requires a 
relatively fatty acid-free olive oil which can be easily prepared. The essential reaction for fatty acids is colorimetric. The lipase activity can be expressed in units. However, as this method has not yet been fully evaluated we would temporarily recommend the method of Cherry \& Crandall, but with considerable reservation. It might be asked why do lipase estimations if amylase estimations can be simply done? The answer is simple. Lipase is practically speaking only of pancreatic origin though there may be a gastric lipase most active at low pH (Bank et al., 1964). Increased serum amylase can be due to many causes such as mumps; lipase elevation does not occur in mumps or in renal decompensation as frequently as does hyperamylasaemia.

The fluids suitable for lipase determination include all those mentioned for amylase apart from urine owing to the possible presence of ill-defined lipase inhibitors.

(c) Faults and sources of error of lipase determinations. (1) Errors in physiological assumption. These have been referred to earlier. The sources of error under this heading are far less frequent than with amylase. We are not aware of any studies on circulating lipase inhibitors or anti-enzymes. Urinary inhibitors are accepted though their source is unknown. It is unlikely that there can be any or many true iso-lipases as the major source of the enzyme is from the pancreas. Hyperlipasaemia may occur following morphine or, possibly, upper abdominal catastrophes.

(2) Technical faults and faulty assumptions. We have dealt with the major difficulties appertaining to older methods which we hope can now be significantly lessened. There are a few further points. Lipase is very sensitive to temperature and the serum or other fluid should be kept at freezing or in the deep freeze if not being immediately evaluated. It is sensitive to $\mathrm{pH}$ and care with regard to this is important.

\section{Other enzymes}

There are a number of other enzymes of pancreatic origin which can be studied but are not ordinarily investigated in clinical chemistry. It is highly probable that some of them may be used in the future as checks on either amylase or lipase activity. This may be required because of doubts as to the significance of an elevation or, occasionally, a depression of an enzyme. It is ordinarily accepted that a principle of parallelism holds for a tissue's mixed enzyme activity but this may not be true and there is increasing physiological evidence that the enzyme content of a gland may be affected by diet and presumably the exocrine secretion or the serum may also be affected (Magee \& Anderson, 1955).
Disease may do the same. Apart from the principle of parallelism it is well to recollect that there is more than one source for amylase even though it may not yet be possible to partition the amylase activity of a biological fluid. This may also be true for lipase activity but to a lesser extent. For these reasons an accurate estimation of the activity of more than one enzyme, especially if a specific origin can be ascribed to it, could be a help.

Up to some years ago methods for the quantitative estimation of trypsin and chymotrypsin were rather crude and not suitable at all for studies of serum activity. With the introduction of new substrates, such as benzoyl-arginine-ethylester in the case of trypsin, the position has changed. It has been claimed that such plasma coagulation factors as antithrombin activity are dependent on the rate at which trypsin enters the blood stream and plasma antithrombin titre is thus an indirect measurement of trypsin activity. The same may be true of other coagulative factors such as antifibrinolysins. Attempts have been made to use plasma antithrombin activity as a method of measuring pancreatic function. The results have not been as consistently helpful as might have been expected. A further difficulty with trypsin extimations may be the presence of trypsin (and, possibly, chymotrypsin) inhibitors. These appear to be present in the normal gland and it would appear that normal serum's tryptic activity is considerably reduced by the presence of inhibitors. Their significance in disease have not yet been fully evaluated, but deficiency of $\alpha$-antitrypsin has been reported. This homozygotically active gene may be associated with a high incidence of chronic obstructive pulmonary disease and a less high incidence of peptic ulceration (Eriksson, 1961).

Apart from the trypsins and related coagulative factors other serum enzymes can be studied such as leucine aminopeptidase. A study of this enzyme was widely promoted some years ago as being especially valuable in the early diagnosis of pancreatic carcinoma. The value of its estimation was thought to be due to a specific pancreatic origin. This is no longer accepted as only marginally true, many other sources being known. Further, abnormal levels of this enzyme have been described in many non-pancreatic, non-malignant diseases and even in physiological states such as pregnancy.

\section{The application of enzyme and related studies to the diagnosis of pancreatic disease}

There are three main sources of pancreatic enzymes ordinarily available - duodenal juice, serum and urine. They can be studied separately or coincidentally if circumstances permit or require. They do not all furnish the same kind of information and 
interpretation of analytical results must be sophisticated. We will discuss the different procedures separately but it should be understood that they cannot be isolated into water-tight compartments.

\section{Duodenal juice}

As ordinarily understood in the field of pancreatic disease this is taken to mean pancreatic juice but this is not accurate. Duodenal juice, for example, contains trypsin, not trypsinogen, and also gastric juice, bile and the secretion of Brunner's glands. To obtain juice a duodenal tube at least must be used, preferably a double lumen tube so as to remove separately gastric and duodenal contents. Duodenal intubation is a difficult procedure to apply in the study of such conditions as acute pancreatitis or other upper abdominal conditions associated with vomiting or severe nausea. Under such circumstances serum or urinary studies should be quite sufficient and afford conclusive information. There is more than one argument in favour of duodenal intubation when practicable. It should demonstrate abnormality due to the following types of pathology. Firstly, if there be stenosis of the pancreatic duct, especially near the Vaterian ampulla, this could cause changes in pancreatic volume flow. Secondly, if there be considerable parenchymal damage bicarbonate and enzyme secretion may be reduced. Finally an ulcerative, including neoplastic, lesion may be recognized by the presence of blood or even malignant cells.

The pancreas secretes a large volume of juice having a high bicarbonate content itself believed to be of ductal origin. The enzymes are secreted in the acini into a fluid containing cations such as sodium and calcium, the chief anion being chloride which later exchanges with bicarbonate secreted by the cells of the intercalary ducts.

There are basically two methods for obtaining pancreatic juice. The first of these is by evoking pancreatic secretion as part of the ordinary response to digestion of a meal such as the standard test meal of Sarles (Sarles, Jodrani-Oswald \& Sarles, 1958) or of Lundh (1962). The enzyme and bicarbonate content approximates to a normal digestive response of the gland under suitably standardized circumstance. As a method of testing secretory response of the pancreas it is somewhat similar to the oldfashioned gruel meal for the study of gastric secretory capacity but it may furnish information especially in regard to the usefulness of a pancreas digestively.

The alternative test is that in which the pancreas is stimulated by physiological stimulants such as secretin alone, or secretin and pancreozymin. Secretin mainly acts as a stimulant of volume and bicarbonate secretion; pancreozymin of enzymes. Relatively pure secretin has been available for some years. Pancreozymin and cholecystokinin are probably identical (E. Jorpes, 1966, personal communication).

Pancreozymin is not available in as pure a preparation as secretin and its standardization is not so precise. Its inclusion in a combined test has not been universally accepted (Dreiling, Janowitz \& Perrier, 1964) though it is the procedure which we favour. Attempts have been made to provide data towards a maximal test. The introduction of a maximal test in the case of the pancreas is probably rarely required for in most, if not all, patients with pancreatic disease we are studying problems of hyposecretion and, provided that the dose of the stimulant given is at least in the physiological range, we are not over-interested in giving what would be a pharmacological dose of the evoking agent. This is, of course, the reverse of the stomach where gastric hypersecretion and resultant peptic ulceration are the predominant clinical problems. The use of pharmacological stimulants such as mecholyl or morphine seems to be no longer required.

\section{Digestive capacity}

This has found favour with a number of authors but we have not used it. It is attractive but in a sense does not afford evidence of such data as pancreatie volume which could be important. Ventzke, Davidson \& Grossman (1964) have reported their experiments with the Lundh test. The information obtained was of enzyme concentration notably trypsin which was present in abnormally low amounts in many pancreatic diseases. It is a simpler test than the evocative tests, studying usually only one enzyme but not volume or bicarbonate concentration. Such a test could well find a useful place in the study of the occasional case of suspected pancreatic disease. We feel that it will not yield as wide a spectrum of information as a well-conducted evocative test either of duodenal contents or of serum.

\section{Evocative tests}

There are two commonly used tests of this sort the secretin test and the secretin-pancreozymin or pancreozymin-secretin test. The secretin test is the older and is quite reliable especially when used in a clinical centre where such tests are not infrequent If proper regard be paid to dose-weight relations the use of this test should give a reasonably profuse response from the normal pancreas and subnormal figures (indicative of disease) should be noticeable. It is worth remembering that secretin only stimulates two of the three important capacities of the exocrine pancreas, volume and bicarbonate secretion, but 
not enzyme secretion, and the combination of a secretin test with blood studies (which can only be on enzymes) gives less information than when an enzyme stimulant like pancreozymin is used. There is possibly another good reason why pancreozymin may be useful in blood studies, that is that it may provide the essential acinar change of permeability for back-diffusion of enzymes which can then be estimated in the serum. Whether there is much to be gained by administering pancreozymin after (Burton et al., 1960a) or before (Sun \& Shay, 1960) secretin has not yet been proven. The tube should be first positioned well proximal to the ligament of Treitz. We have used the secretin-pancreozymin sequence of Burton et al. (1960a) particularly because this sequence can easily be applied to serum studies also. We should emphasize that in most or nearly all cases of pancreatic disease where these duodenal studies are used the special interest is in the possibility of deficiency rather than hypersecretion. Provided that such technical aspects as the availability of a suitable double lumen tube and its proper positioning is accomplished the vigour of pancreatic stimulation (above certain minimal limits) is less important.

\section{Technique of secretin or secretin-pancreozymin test}

A suitable double lumen gastro-duodenal tube, such as the Dreiling or Lagerlof tube, is swallowed the evening before the test and positioned fluoroscopically the following morning so that the tip of the tube is some inches proximal to the duodenojejunal flexure and that suction on each of the two tubes gives, on the one hand, clear, usually acid, gastric juice and, on the other hand, clear, possibly bile-stained and alkaline, duodenal juice. If coincidental serum studies are planned a preliminary collection period of $1 \mathrm{hr}$ is usual after which secretin (Boots or Vitrum) in a dose of $1.0 \mathrm{unit} / \mathrm{kg}$ is injected intravenously. Collection at 10-min intervals up to $20 \mathrm{~min}$ and then at 20-min intervals for another $60 \mathrm{~min}$ is the most widely used procedure. If it is proposed to use pancreozymin in addition to this substance (Boots or Vitrum) 1.7 units $/ \mathrm{kg}$ well diluted to $20 \mathrm{ml}$ saline is slowly injected at $30 \mathrm{~min}$ from zero intravenously (mainly to avoid local thromboses but also abdominal cramps) and then further collections carried on for a further $120 \mathrm{~min}$ at 20-min intervals. Salivary suction during this test should be done so as to prevent swallowing of saliva but this should not affect the issue if good gastric suction had been available.

It is important, though not always practised, to keep all samples at freezing point as enzymes such as lipase are very sensitive to temperature. The following studies are usual in the duodenal juice: volume, bicarbonate concentration, enzyme content usually amylase and lipase (trypsin rather than amylase in infants), guiac or benzidine reaction, biliary pigment concentration and cellular pattern.

\section{Faults and sources of error in evocative duodenal studies}

(1) Errors in physiological assumption. The most significant error in this field is the assumption that either secretin or pancreozymin is pure as ordinary available. This is particularly not true for pancreozymin which may often contain a considerable mixture of secretin. It is indistinguishable from cholecystokinin (E. Jorpes, 1966, personal communication) which might be useful in studying biliary flow but contributes no useful information in relation to the pancreas. Secretin stimulates bile flow also. We are thus dealing with hormonal substances with double actions on both pancreas and liver. Even the purest preparation as yet available shows this double effect. Furthermore, pancreozymin requires a certain degree of vagal tone and if this varies it may affect dose-response relations greatly. It is almost certainly wiser to estimate the level of more than one enzyme rather than say amylase alone. This is accepted for infants especially in whom amylase activity is very low at birth and for this reason trypsin estimations have been the accepted alternative. In the adult, owing to some curious devotion to a hitherto unproved and almost certainly incorrect principle of parallelism, the practice of using one enzyme as a complete check on acinar capacity to secrete all other appropriate enzymes is unwise. It may ordinarily be perfectly valid especially in inflammatory states (Burton et al., 1960a) but not in those disorders with a large nutritional background such as pancreatic fibrosis in nutritional deficiency states.

(2) Errors in technique. Introduction of the tube is not pleasant and if much nausea be evoked this may lead to duodeno-gastric regurgitation and also to decreased pancreatic response to the hormones themselves. If the tube be incorrectly positioned there may be considerable loss of duodenal contents. There are other possible technical faults: for example, where such a degree of peristaltic stimulation occurs from the pancreozymin that one cannot but be unhappy about the efficiency of suction from the intestinal tube.

\section{Serum studies}

The recognition of high serum levels of such enzymes as amylase or lipase has long been accepted as significant of acute pancreatitis. The levels rise very rapidly after the onset of pain but do not go in exact parallel. Although, hitherto, serum 
amylase determination has been much simpler and far quicker than that of serum lipase it should be remembered that it is much less specific and that, if in doubt or, perhaps, anyhow, if a simple serum lipase test is available, this should also be done. It has been uncommon to study serum levels of trypsin. How high do the enzyme levels ordinarily go in acute pancreatitis? They may increase to ten times the normal value and only slowly return. This increase may be exaggerated in the presence of an associated oliguria produced by hypovolaemia.

The position in chronic pancreatitis is quite different. Here resting serum levels may be within the normal range though we have an impression that high normal figures should be viewed with suspicion (FitzGerald, FitzGerald \& McMullin, 1964). This is the area where an evocative serum study may be of great diagnostic assistance. In a pancreas damaged by disease two major changes may occur which may lead to increased serum enzyme levels following a stimulus. The first of these is well known and widely accepted-that under conditions of increased secretory pressure evoked by a hormonal stimulus, ductal stenosis will lead to increased back pressure and thus the enzyme may pass into the intercellular spaces and the circulating blood. We suspect that a hormone such as pancreozymin, which acts at acinar levels, will provoke increased back-diffusion if acinar basement membrane and pancreatic lymph drainage be abnormal in a patient with pancreatic damage. A rapid rise in serum levels possibly indicates the presence of stenosis in the duct of a relatively healthy gland (FitzGerald et al., 1964).

\section{Technique}

The dose of secretin and of pancreozymin used is exactly that for the intubation test (Burton et al., $1960 \mathrm{~b})$. Typically the serum test will go on for 3 $\mathrm{hr}$ or more. Specimens should be kept at freezing before study.

\section{Faults and sources of error in evocative serum tests}

(1) Errors in physiological assumption. It is well to remember that there is more than one source for serum amylase, fewer for lipase and trypsin. For all that, amylase has usually been the basic enzyme studied and owing to its technical simplicity it may continue to be. Trypsin estimations are possibly more specific but here the presence of circulating antienzymes or inhibitors is not infrequent, they themselves having been released by the pancreas or formed in vivo. Amylase or lipase inhibitors are not unsuspected: the suspicion that there could be circulating inhibitors to these enzymes has probably become weaker and has been, in the case of serum amylase, replaced by the possibility of a modified amylase or an iso-amylase. We have referred earlier to other causes of hyperenzymaemia than those due to actual pancreatic disease, e.g. morphine, uraemia, etc.

(2) Errors in technique. It is important that the pancreozymin solution should be well diluted and given slowly in order to avoid local venous thrombosis. We have not experienced sensitivity reactions to either secretin or pancreozymin even with repeated tests in up to 500 serum evocative tests. Serum samples should be kept cold and serum specimens stored in the refrigerator or the deep freeze.

\section{Urine studies}

(1) Amylase. One of the earliest methods of recognition of acute pancreatitis was a quantitative study of urinary amylase frequently in 24-hr specimens (Corbett, 1913). The method required need not be sensitive but we feel that it should be similar in sensitivity to a serum method. Thus dilution of the urine specimen may be required especially in a case of acute pancreatitis. It might be thought that studies of urinary amylase levels are no longer required but this view is not universally accepted for a number of reasons. Elevation of urinary amylase levels occurs early in acute pancreatitis and may remain at abnormally high levels for a considerable time after serum levels have returned to normal. We are unaware of any studies in which a sensitive amylase technique has been applied to serum estimations and then compared with urine levels. Using less sensitive serum techniques this observation may be more correct and diagnostically significant. We do not ordinarily apply it but on occasions the information obtained has been useful. Urinary amylase studies have been reported to be more frequently abnormal in chronic pancreatic disease than are serum levels after secretin alone or secretin plus pancreozymin (Corbett, 1913).

\section{Faults and sources of error in study of urinary amylase}

(a) In physiological assumption. There are a number of faulty assumptions which must be referred to. Amylase can only be excreted when relatively free (Kirshen, Gambill \& Mason, 1965). Certain forms of macrogammaglobulin (Wilding et al., 1964) may be associated with such firm protein binding of amylase that it cannot be excreted. This is probably a rare situation. Amylase is excreted by glomerular filtration (with doubtful tubular involvement) and if this be subnormal due either to intrarenal disease or to such extrarenal factors as the shock state associated with acute pancreatitis, urinary enzyme levels may not mirror serum levels. 
It is important to remember that the pancreas is not the sole source of amylase. There is some evidence that pancreatic and salivary amylases have different electrophoretic mobility and thus are probably true iso-enzymes (Aw, 1966).

(b) In technique. There are potentially few sources of error. Even in the absence of proper 24-hourly specimens abnormal concentration of urinary amylase is probably significant provided that the effect of shock on urinary output is not forgotten.

(2) Lipase. There is some doubt as to the usefulness of urinary lipase studies. The mechanism of excretion is not clear. It has been claimed that activity is suppressed to a greater or lesser degree by the presence of inhibitors. There have been a limited number of publications of urinary lipase studies. We do not ordinarily use urinary lipase studies in the diagnostic clinical field.

\section{Stool trypsins}

Pancreatic enzymes are normally absorbed from or destroyed in the adult intestine. This is not so in the infant where absence of trypsin in a stool specimen is suggestive of a diagnosis of mucoviscidosis. However, there have been attempts to demonstrate the presence of trypsin or chymotrypsin in the stool of normal adults. The specificity of these tests is open to question and anyhow there would appear to be no place for so crude a test in this field. If pancreatic deficiency has developed to the degree that abnormally small amounts of trypsin are being excreted it can be assumed that, even allowing for a minor degree of parallelism, lipase and amylase will also be deficient and that steatorrhoea will be quite evident.

\section{Other body fluids}

Amylase, lipase or tryptic activity in peritoneal pleural or pericardial fluids may be of occasional diagnostic help. The presence of any two of these enzymes in such fluids is of high diagnostic significance. This occurs typically in acute pancreatitis. It has been most frequently studied in aspirates from the peritoneal cavity which have been described as having the appearance of raw beef broth.

\section{Other tests of pancreatic function}

We have referred to the various direct tests of pancreatic function. There are a number of other useful tests. They are rather widely used, sometimes, we suspect, under the impression that they will afford a more reliable measure of pancreatic function than a direct test. In the majority of cases two functional capacities, digestion and absorption, may be checked against the single capacity of absorption. If absorption appears to be abnormal this would appear to exculpate the pancreas as being the cause of a steatorrhoea. This conclusion may be unsophisticated as it hardly considers the possibility of a double pathology. Sometimes quite different substances are used as a check on one another. Empirically, there is no doubt that in most cases this will lead to an accurate conclusion: but this need not always happen.

Some tests may be suggestive because they are double tests using the same test substance in two different forms as part of a double test. These tests can give a considerable amount of information, but labour under some objections. It should be noted that nearly all these tests only suggest the presence of pancreatic disease when the gland is decompensated. They can be categorized as follows:

1. Evaluation of possibly depressed pancreatic function: (a) Tests dependent upon potentially different metabolic requirements for two forms of the substance, i.e. vitamin $A$ alcohol and acetate or triolein ${ }^{131} \mathrm{I}$ and oleic acid ${ }^{131} \mathrm{I}$; (b) tests dependent upon demonstrating the high probability that an abnormality which could be due either to faulty digestion or absorption of a fat is likely, when tested more specifically, to be due to one of these functions; and (c) study of possible damage to other than exocrine pancreas, cf. beta cells.

II. Specialized tests used in aetiological evaluation. Such are sweat electrolyte or amino-acid studies.

III. Biopsy.

IV. Diagnostic photoscanning.

V. Electrocardiography.

VI. Radiology (dealt with elsewhere).

1. Evaluation of possibly depressed pancreatic function A. Tests dependent upon potentially different metabolic requirements

(i) Starch test. The possibility that in amylase deficiency due to pancreatic disease starch would be significantly less efficiently metabolized than glucose has formed the basis for a test (Althausen \& Uyeyama, 1954). It is not as useful as the following tests.

(ii) Vitamin A test. Vitamin $\mathrm{A}$ is absorbed by somewhat similar mechanisms to those used for fats. An esterified form of the vitamin such as the acetate requires to be transformed into the alcoholic form before absorption (after which it is esterified again as a propionate). We have usually used a test-dose of 250,000 units of either form of the vitamin (kept in nitrogen) given to the fasting and resting patient with a carrier dose of milk (FitzGerald, Fennelly \& Hingerty, 1962). In practice, if the acetate be first used and gives a poor response (800 I.U.) this suggests a steatorrhoeic state (but non-specifically) and must be tested further by 
using the alcohol. If the serum rise after the latter be greater than 800 I.U. this suggests a pancreatogenous steatorrhoea. If both are low this suggests an absorption deficiency.

(iii) Tagged fat studies. Fat is absorbed predominantly as fatty acid and/or monoglyceride. This is true particularly of the ordinary dietary long carbon-chain fats rather than the medium or short carbon-chain fats. Dietary fat is, after mixing in the stomach, digested by pancreatic lipase in the presence of bile salts and bicarbonate and enmeshed into a network or micelle from which it is absorbed into the villus. This complicated sequence may be interrupted in many ways notably by lipase deficiency.

If a neutral fat such as triolein and its fatty acid, oleic acid, were tagged with a firmly bound radioisotope the course of digestion and absorption could be followed. The chief isotope used hitherto has been ${ }^{131}$ I used as a label of both fats on separate days. We have studied chiefly the serum levels which give a good correlation with vitamin A studies but less close with levels of faecal fat if they are used as an index of malabsorption or maldigestion (FitzGerald et al., 1962). It is again important to study the resting, fasting patient. We use milk as a carrier. The patient should remain at rest.

\section{B. Tests depend upon an abnormality of either fat digestion or fat absorption}

(i) Fat balance. The normal adult on a fat intake between 50 and $120 \mathrm{~g} /$ day will not lose more than $5.0 \mathrm{~g}$ fat in the stool, certainly not more than $7 \cdot 0 \mathrm{~g}$. If he does so he is suffering from steatorrhoea either due to poor fat digestion (typically, pancreatogenous) or to malabsorption. A faecal fat estimation should not be studied for at least 5 days after a barium meal.

The fat balance we have used has been exactly the same as that used for study of a possible case of malabsorption. When pancreatitis is suspected a steatorrhoea must be cross-checked by using a substance normally easily absorbed and not requiring pancreatic digestion.

(ii) Faecal nitrogen. Excessive amounts of faecal nitrogen occur in the presence of either malabsorption or pancreatic deficiency. Creatorrhoea (i.e. undigested meat fibres in the stool) is characteristic of the latter and may be recognized microscopically.

(iii) $d$-Xylose. This pentose sugar is absorbed especially in the upper small intestine. Apparently about $50 \%$ of the amount absorbed is metabolized and the remainder excreted; this latter amount giving an index of absorptive capacity. Originally $25 \mathrm{~g} d$-xylose was used but more recently a $5.0 \mathrm{~g}$ dose has been suggested. Urinary $5-\mathrm{hr}$ excretion should be greater than $2.5 \mathrm{~g}$ after $25 \mathrm{~g}$ or greater than $1.0 \mathrm{~g}$ after $5.0 \mathrm{~g}$. If this test be normal in the presence of steatorrhoea pancreatic deficiency is suggested.

(iv) Folic acid studies. Folic acid is specifically absorbed in the jejunum. The intestine's absorptive capacity for folic acid can be evaluated directly or indirectly.

(a) Direct study. Give $40 \mu \mathrm{g} / \mathrm{kg}$ body weight of folic acid orally to the fasting patient, blood being taken at zero time and $2 \mathrm{hr}$ later. Serum folate is determined microbiologically in terms of capacity to promote growth of $L$. case $i$. Fasting levels may suggest deficiency confirmed by the postabsorptive figures. Pregnancy may affect this test.

(b) Indirect Figlu test. The amino acid histidine is metabolized to glutamic acid in the presence of normal serum folate levels. Otherwise the metabolic chain is interrupted at the level of formiminoglutamic acid (figlu) which is then excreted in abnormal amounts in the urine. This test may be abnormal in post-gas rectomy steatorrhoea, iron deficiency anaemia, pernicious anaemia and some complicated liver diseases without actual folic acid deficiency. This test may be affected by the presence of concomitant liver disease notably hepatic cirrhosis.

\section{Damage to other than exocrine pancreas}

Carbohydrate metabolism. Severe pancreatic damage may lead to temporary or permanent interference with islet cell function. The former typically occurs during acute pancreatitis; glycosuria and/or hyperglycaemia should be sought for during an attack. Their presence both suggests that the attack is severe and also should modify intravenous medication. Abdominal pain in a diabetic, especially a juvenile, may be due to pancreatitis.

In chronic pancreatitis of any form glycosuria may occur and its presence also implies a seriously damaged gland. More typically, glucose tolerance may be abnormal and figures of a diabetic incidence of up to $50 \%$ in chronic pancreatitis have been claimed. We believe that this figure should be much lower (c. $10 \%)$ and that a high incidence in a series merely indicates a preponderance of advanced cases and that either the diagnosis of pancreatitis has been too reluctantly made in many patients (not included) or that diabetes has been diagnosed over-frequently. This last could be the result of an excessively large glucose load in a middle-aged patient or by the combination of other stressors such as steroids with that load. We ordinarily carry out a simple glucose tolerance study using a dose of $1 \mathrm{~g}$ glucose $/ \mathrm{kg}$ body weight.

Plasma insulin assays are now possible in special centres. Normal plasma insulin levels which do 
not change after a glucose load have been reported in chronic pancreatitis (Peters et al., 1966).

\section{Specialized tests}

(a) Calcium metabolism. It appears that there is an increased incidence of pancreatitis in hyperparathyroidism (Mixter et al., 1962). The percentage incidence of hyperparathyroidism in any group of patients with chronic pancreatitis is probably low. Calcium studies should form an essential part of the work-up of patients. A case of acute pancreatitis due to hypervitaminosis $\mathbf{D}$ has been reported (Leeson \& Fourman, 1966).

Hypocalcaemia may develop during episodes of acute pancreatitis. Levels below $7 \mathrm{mg} / 100 \mathrm{ml}$ are of grave significance. The hypocalcaemia is due to the binding of serum calcium in areas of fat necrosis. Tetany may occur even with normal serum calcium levels when circulating soaps may bind the serum calcium.

(b) Urinary amino acids. The presence of leucine and cystine in abnormal amounts may be associated with hereditary pancreatitis but can appear in members of these families without this accompaniment. We have seen two families with hereditary pancreatitis in Ireland.

(c) Sweat and salivary electrolytes. These are found to be elevated in patients with mucoviscidosis. It is usually stated that they are not elevated in patients with the adult form of pancreatitis (Di Sant'Agnese et al., 1953) but French workers have been less positive (Sarles et al., 1965). Mucoviscidosis may present as a form of progressive pancreatic insufficiency, typically painless, in the adult.

(d) Blood count and iron studies. It has been recognized for some time that chronic pancreatitis (provided it is not complicated by bleeding) is not associated with iron deficiency anaemia despite considerable exocrine insufficiency. The usefulness of this observation for diagnostic purposes is limited.

(e) Serum proteins. Serum proteins are usually not affected in the presence of pancreatic disease unless secondary deficiency states have developed. We have discussed earlier the historical development of the idea that serum albumin, as well as $\gamma$-globulin, could bind amylase.

\section{Biopsy}

It would be satisfactory if needle biopsy of the pancreas could be carried out without open operation. There are difficulties which should be noted. Pancreatitis is more frequently oedematous, the histology being banal or minimally abnormal. It is, of course, possible to obtain histological proof of pancreatitis but this will not be so in earlier cases.
It may be possible to exclude the pancreas as a major cause of steatorrhoea by small intestinal biopsy. If there be mucosal atrophy this might be taken to indicate a malabsorption cause of the steatorrhoea. We have, however, seen at least one patient exhibiting pancreolithiasis and mucosal atrophy (FitzGerald et al., 1963).

\section{Diagnostic photoscanning}

Selenomethionine $\left({ }^{75} \mathrm{Se}\right)$ is taken up selectively by the pancreas. It has an effective half-life in the pancreas of $24 \mathrm{hr}$. Uptake is impaired in the presence of pancreatic damage and photoscanning may be useful in the study of cases of suspected pancreatitis. It is unlikely that it will be abnormal in the early compensated phase of the disease. We have no personal experience of its use.

\section{Electrocardiography}

Considerable E.C.G. changes can occur in association with acute pancreatitis notably depression of ST segments, inverted T waves or prolonged QT segment. These may not always be due to myocardial involvement and may be reversible unless they are due to concomitant coronary occlusion, a well-documented possibility. Serum studies should clarify the situation but a sophisticated clinical approach is essential in such situations.

\section{Application of tests}

We have, in the previous pages, endeavoured to enumerate and classify nearly all the tests which are used in the diagnosis of acute and chronic pancreatitis. It is important to summarize them so that they can be applied in a rational manner. Tests suitable for the diagnosis of acute pancreatitis are of little value in the study of the chronic disorder when the disease process is changing slowly. They may be only moderately outside the normal range. Usually there is no urgent call for a precise diagnosis. In the acute disease minutes may count; changes from the normal, typically are considerable and some tests (e.g. duodenal enzyme studies) are inapplicable for obvious technical reasons. The following tables summarize the tests which would be useful in the diagnosis of acute and chronic pancreatitis.

\section{Acute pancreatitis}

and recurrent acute pancreatitis

Table 1 gives a brief indication of the tests most suitable for the diagnosis of these conditions. They have been considered in detail earlier and are here summarized. 
TABLE 1

Acute pancreatitis

\begin{tabular}{|c|c|c|c|c|}
\hline Fluid studied & Substance studied & Technique & Normal range & Diagnostic range \\
\hline Serum & Amylase & Saccharogenic & $1 \cdot 5-3 \cdot 0 \mathrm{mg} / \mathrm{ml}$ & $>3.0 \mathrm{mg}$ \\
\hline Serum & Lipase & $\begin{array}{l}\text { See reference } \\
\text { but vide supra }\end{array}$ & $\begin{array}{l}<1 \cdot 3 \mathrm{ml} \mathrm{N} / 20 \\
\mathrm{NaOH}\end{array}$ & $>1 \cdot 3 \mathrm{ml}$ \\
\hline Urine & Amylase & Saccharogenic & $\begin{array}{l}300 \text { Somogyi } \\
\text { units/hr }\end{array}$ & $>500$ units $/ \mathrm{hr}$ \\
\hline $\begin{array}{l}\text { Peritoneal } \\
\text { pleural, } \\
\text { pericardial }\end{array}$ & $\begin{array}{l}\text { Amylase, } \\
\text { lipase or } \\
\text { trypsin }\end{array}$ & See text & $\begin{array}{l}\text { Anything above } \\
\text { normal serum } \\
\text { range }\end{array}$ & $\begin{array}{l}\text { None normally } \\
\text { present }\end{array}$ \\
\hline Serum & Calcium & Chemical & $9-11 \mathrm{mg} / 100 \mathrm{ml}$ & $8.0 \mathrm{mg} / 100 \mathrm{ml}$ \\
\hline
\end{tabular}

False positives False negatives and comments

Yes: Abdominal Possibly in advanced emergencies, mumps, liver disease, uraemia pancreatitis with superimposed acute pancreatitis

Apparently rare May take some hours to including renal failure be elevated

As for serum except Especially uraemia uraemia

Not described

Only + if exudate direct result of pancreatic enzymes

Should not ordinarily Normocalcaemic tetany occur but acute

pancreatitis may mask may occur when circucalcium, lessening ionic calcium, lesse
proportion

\begin{tabular}{|c|c|c|c|c|c|c|c|}
\hline Serum & $\begin{array}{l}\text { Phosphate and } \\
\text { phosphatase }\end{array}$ & $\begin{array}{l}\text { Standard } \\
\text { techniques }\end{array}$ & $\begin{array}{l}\text { Usual } \\
\text { figures }\end{array}$ & $\begin{array}{l}\text { Usual } \\
\text { figures }\end{array}$ & $\begin{array}{l}\text { Used as check on the } \\
\text { significance of calcium } \\
\text { figures }\end{array}$ & \multicolumn{2}{|c|}{$\begin{array}{l}\text { Used as check on the } \\
\text { significance of calcium } \\
\text { figures }\end{array}$} \\
\hline Blood & Sugar & $\begin{array}{l}\text { Glucose } \\
\text { oxidase }\end{array}$ & $78-88 \mathrm{mg} / 100 \mathrm{ml}$ & $>160 \mathrm{mg} / 100 \mathrm{ml}$ & $\begin{array}{l}\text { In presence of post- } \\
\text { mature } D \text {. mellitus }\end{array}$ & \multicolumn{2}{|c|}{$\begin{array}{l}\text { Only abnormal in } 10 \% \\
\text { of cases }\end{array}$} \\
\hline Urine & Sugar & $\begin{array}{l}\text { Reducing test } \\
\text { or glucose } \\
\text { oxidase }\end{array}$ & Zero & +1 test & $\begin{array}{l}\text { Any }+ \text { test for sugar } \\
\text { in presence of } \\
\text { abdominal pain } \\
\text { suspicious }\end{array}$ & \multicolumn{2}{|c|}{$\begin{array}{l}\text { Increased renal threshold } \\
\text { of older age may give } \\
\text { false test }\end{array}$} \\
\hline $\begin{array}{l}\text { Faeces } \\
\qquad *(2)\end{array}$ & Fat & Naked eye & No globules & Globules + & Liquid paraffin & Frequent & $\begin{array}{l}\text { Not of much } \\
\text { importance }\end{array}$ \\
\hline Faeces & Fat & Fat balance & $\begin{array}{l}5 \mathrm{~g} / \text { day } \\
5-7 \mathrm{~g} \text { doubtful }\end{array}$ & $\begin{array}{l}5 \mathrm{~g} / \text { day doubtful } \\
>7 \mathrm{~g} \text { certain }\end{array}$ & $\begin{array}{l}\text { Malabsorption } \\
\text { or maldigestion }\end{array}$ & Frequent & $\begin{array}{l}\text { Must be cross } \\
\text { checked against } \\
\text { pure test of } \\
\text { absorption }\end{array}$ \\
\hline
\end{tabular}

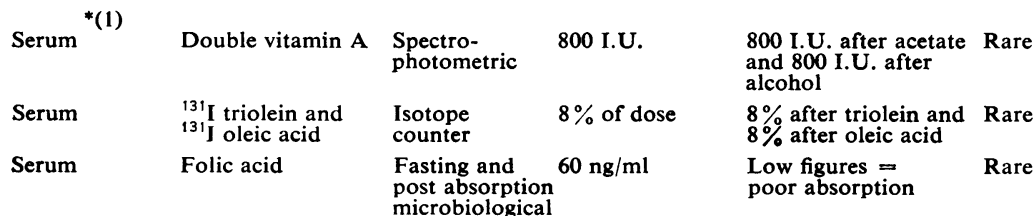

$\begin{array}{lllll}\text { Urine } & \text { Figlu } & \text { Chemical } & \begin{array}{l}0-5 \mathrm{mg} / \mathrm{hr} \text { for } \\ 6 \mathrm{hr} \text { post } 20 \mathrm{~g}\end{array} & \text { Over } 5 \mathrm{mg} / \mathrm{hr} \\ \text { L-histidine }\end{array}$

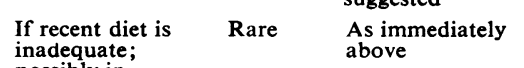

Frequent Useful if available

Frequent Simple test

Excessive If steatorrhoea is utilization present and this test is normal, pancreatic disease suggested inadequate possibly in Unpredictable in Rare As above diabetes

A suggestive test

Rare

Hyperglycaemia plus abdominal pain suggests pancreatitis

\begin{tabular}{|c|c|c|c|c|c|}
\hline Blood & $\begin{array}{l}\text { Sugar tolerance } \\
1 \mathrm{~g} / \mathrm{kg} \text { body weight }\end{array}$ & Chemical & $180 \mathrm{mg} / 100 \mathrm{ml}$ & $>180 \mathrm{mg} / 100 \mathrm{ml}$ & Can occur \\
\hline Serum & Calcium & Chemical & $9-11 \mathrm{mg} / 100 \mathrm{ml}$ & $>11 \mathrm{mg} / 100 \mathrm{ml}$ & Uncommon \\
\hline
\end{tabular}

Uncommon As above

Uncommon Serum calcium elevation
(checked by phosphate and phosphatase) suggests hyperparathyroidism. Uncommon may be familial

Sweat $\dagger$ an Electrolytes

Chemical $\mathrm{Na}<60 \mathrm{mEq} \quad>60 \mathrm{mEq}$

Uncommon

Typically abnormal in mucoviscidosis but can be abnormal in less grave diseases

Urine $†$ Amino acids especially leucine and cystine

Chromato- Trace + graphy or
microbiological
When definitely Yes positive 
TABLE 2

(a) Laboratory tests for chronic pancreatitis

\begin{tabular}{|c|c|c|c|c|c|c|c|}
\hline Source studied & $\begin{array}{l}\text { Substance } \\
\text { studied }\end{array}$ & Technique & Normal range & $\begin{array}{l}\text { Diagnostic } \\
\text { range }\end{array}$ & False positives & False negatives & Comments \\
\hline \multicolumn{8}{|l|}{$*$} \\
\hline $\begin{array}{l}\text { Serum (fasting } \\
\text { or post- } \\
\text { prandial) } \\
\\
*\end{array}$ & Amylase & As Table 1 & As Table 1 & As Table 1 & As Table 1 & Not relevant & $\begin{array}{l}\text { Uncommon } \\
\text { to find tests } \\
\text { definitely } \\
\text { abnormal }\end{array}$ \\
\hline $\begin{array}{l}\text { Serum (fasting } \\
\text { or post- } \\
\text { prandial) }\end{array}$ & Lipase & As Table 1 & As Table 1 & As Table 1 & Rare & Not relevant & $\begin{array}{l}\text { Uncommon } \\
\text { to find tests } \\
\text { definitely } \\
\text { abnormal }\end{array}$ \\
\hline $\begin{array}{c}*(1) \\
\text { Serum post- } \\
\text { evocative }\end{array}$ & Amylase & As Table 1 & As Table 1 & $\begin{array}{l}\text { Rising curve } \\
\text { especially when } \\
>3.0 \mathrm{mg} / \mathrm{ml}\end{array}$ & Rare & $\begin{array}{l}\text { Theoretically } \\
\text { in old standing } \\
\text { pancreatitis; } \\
\text { actually not } \\
\text { always so }\end{array}$ & $\begin{array}{l}\text { Test fre- } \\
\text { quently ab- } \\
\text { normal in } \\
\text { presence of } \\
\text { disease }\end{array}$ \\
\hline $\begin{array}{c}*(1) \\
\text { Serum post- } \\
\text { evocative }\end{array}$ & Lipase & As Table 1 & As Table 1 & As Table 1 & Rare & $\begin{array}{l}\text { Theoretically } \\
\text { in old standing } \\
\text { pancreatitis; } \\
\text { actually not } \\
\text { always so }\end{array}$ & $\begin{array}{l}\text { Test fre- } \\
\text { quently ab- } \\
\text { normal in } \\
\text { presence o } \\
\text { disease. } \\
\text { Confirma- } \\
\text { tory of } \\
\text { amylase } \\
\text { figures }\end{array}$ \\
\hline \multicolumn{8}{|c|}{$\begin{array}{l}\stackrel{*(2)}{ } \\
\text { Duodenal juice. } \\
\text { See Table 2(b) }\end{array}$} \\
\hline Urine & Amylase & As Table 1 & As Table 1 & As Table 1 & Rare & $\begin{array}{l}\text { Can happen, } \\
\text { not in- } \\
\text { frequently }\end{array}$ & $\begin{array}{l}\text { We do not } \\
\text { use it } \\
\text { frequenty }\end{array}$ \\
\hline
\end{tabular}

* Regularly used tests for primary diagnosis-may do serum or duodenal studies, sometimes both.

(b) Normal duodenal volume, bicarbonate, amylase and lipase figures after secretin-pancreozymin stimulation

\begin{tabular}{|c|c|c|}
\hline Activity studied & $\begin{array}{l}\text { Mean normal response per } \mathrm{kg} \\
\text { and lower limit of normal in } \\
\text { parentheses }\end{array}$ & Comments \\
\hline Volume response & $\begin{array}{l}3.75 \mathrm{ml} / \mathrm{kg} \\
(2 \cdot 23 \mathrm{ml} / \mathrm{kg})\end{array}$ & $\begin{array}{l}\text { (a) Total deficiency occurs in obstructive pancreatic carcinoma } \\
\text { involving all ducts and in advanced chronic pancreatitis } \\
\text { (b) Deficiency of volume alone occurs in carcinoma of the head } \\
\text { or body of the pancreas }\end{array}$ \\
\hline Bicarbonate response & $\begin{array}{l}0.31 \mathrm{mEq} / \mathrm{kg} \\
(0.18 \mathrm{mEq} / \mathrm{kg})\end{array}$ & $\begin{array}{l}\text { (c) Normal volume and low bicarbonate with or without low } \\
\text { enzyme concentration suggestive of chronic pancreatitis } \\
\text { (d) Depression of enzymes alone suggests nutritional and } \\
\text { metabolic pancreatic disturbance and other diseases } \\
\text { (1) Burton et al. (1960a) } \\
\text { (2) Dreiling \& Janowitz, (1961) Ciba Foundation Symposium }\end{array}$ \\
\hline $\begin{array}{l}\text { Amylase } \\
\quad \text { (Myers, Free \& } \\
\text { Rosinski } \div 100)\end{array}$ & $\begin{array}{l}17.3 \text { units } / \mathrm{kg} \\
(3.5 \text { units } / \mathrm{kg})\end{array}$ & \\
\hline $\begin{array}{l}\text { Lipase } \\
\quad \text { (Cherry \& Crandall } \\
\quad \div 100)\end{array}$ & $\begin{array}{l}37 \text { units/kg } \\
\text { (3 units/kg) }\end{array}$ & \\
\hline
\end{tabular}


Recurrent chronic pancreatitis and chronic

\section{pancreatitis}

These conditions offer a greater diagnostic challenge than does acute pancreatitis which, at least once it has been thought of, can be firmly diagnosed or excluded. With the chronic disease a tentative clinical diagnosis may not be entertained sufficiently frequently, we believe, but even if considered may not be confidently made. A direct type of test such as the estimation of enzyme activity is to be preferred. We always would use it except under one circumstances-steatorrhoea combined with pancreolithiasis is likely to be pancreatogenous, though it might bear with some study (Table 2).

\section{Acknowledgments}

The author wishes to express thanks to Mr K. McGeeney and Dr M. Carey for helping to prepare this paper and also to the Medical Research Council of Ireland for assistance over many years.

\section{References}

Althausen, T.L. \& Uyeyama, K. (1954) A new test of pancreatic function based on starch tolerance. Ann. intern. Med. 41, 563.

Aw, S.E. (1966) Separation of urinary isoamylases on cellulose acetate. Nature (Lond.), 209, 298.

Bank, S. Krut, L.H., Marks, I.N., Bronte-Stewart, B. \& UYS, P.J. LER. (1964) Hydrolysis of fat by human gastric juice. Gut, 5, 480.

Berk, J.E., Searcy, R.L., Hayashi, S. \& Ujihira, I. (1965) Distribution of serum amylase in man and animals. J. Amer. med. Ass. 192, 389.

Burton, P., Evans, D.G., Harper, A.A., Howat, H.T., Oleesky, S. \& VARLeY, H. (1960) Test of pancreatic function in man based on the analysis of duodenal contents after administration of secretin and pancreozymin. Gut, 1, 111.

Burton, P., Hammond, E.M., Harper, A.A., Howat, H.T., SCOTt, J.E. \& VARLeY, H. (1960b) Serum amylase and serum lipase levels in man after administration of secretin and pancreozymin. Gut, 1, 125.

Carey, M., FitzGerald, O. \& McGeeney, K. (1967a) In preparation.

Carey, M., FitzGerald, O. \& McGeeney, K. (1967b) In preparation.

Cherry, I.S. \& Crandall, L.A. (1932) The specificity of pancreatic lipase: Its appearance in the blood after pancreatic injury. Amer. J. Physiol. 100, 266.

CORBETT, D. (1913) The quantitative estimation of amylolytic ferments in the urine as a measure of certain pathological conditions. Quart. J. Med. 6, 351.

Di Sant 'Agnese, P.A., Darling, R.C., Perera, G.A. \& ShEA, E. (1953) Abnormal electrolyte composition of sweat in cystic fibrosis of the pancreas. Pediatrics, 12, 549.

Dreiling, D.A. \& JANOWITZ, H.D. (1962) Measurement of pancreatic secretory function. The Exocrine Pancreas, p. 225. Ciba Foundation Symposium. Churchill, London.

Dreiling, D.A., JANOWITZ, H.D. \& JOSEPHBERG, L.J. (1963) Serum iso-amylases. Ann. intern. Med. 58, 235.

Dreiling, D.A., Janowitz, H.D. \& Perrier, C.V. (1964) Pancreatic Inflammatory Disease. Harper \& Row, New York.

Elman, R. \& McGoughan, J.E. (1927) The quantitative determination of blood amylase with the viscosimeter. Arch. intern. Med. 40, 58.
ErIKSSON, S. (1961) Studies in $a_{1}$-antitrypsin deficiency. Acta. med. scand. 177, Suppl. 432.

FitzGerald, O. (1955) Pancreatitis following pregnancy. Brit. med. J. i, 349.

FitzGerald, O., Fennelly, J. \& Hingerty, D.J. (1962) Serum studies in man after administration of vitamin A acetate and vitamin A alcohol. Gut, 3, 74.

FitzGerald, O., FitzGerald, P., Fennelly, J., McMullin, J.P. \& Boland, S.J. (1963) A clinical study of chronic pancreatitis. Gut, 4, 193.

FitzGerald, O., FitzGerald, P. \& McMullin, J.P. (1964) Chronic pancreatitis: A Review. Rev. Surg. 21, 77.

Hayashi, S., Searcy, R.L., Berk, J.E. \& Hardy, E.M. (1966) Search for a naturally occurring amylase inhibitor in human serum. Nature (Lond.), 210, 92.

Kirshen, R., Gambill, E.E. \& Mason, H.L. (1965) Comparison of urinary and serum amylase values following pancreatic stimulation in patients with and without pancreatic disease. Gastroenterology, 48, 579.

Leeson, P. \& Fourman, P. (1966) Acute pancreatitis from vitamin $D$ poisoning in a patient with parathyroid deficiency. Lancet, i, 1185.

LUNDH, G. (1962) Pancreatic enzyme function in neoplastic and inflammatory disease: A simple and reliable test. Gastroenterology, 42, 275.

McGeachin, R.L. \& ReYnolds, J.M. (1959) Differences in mammalian amylases demonstrated by enzyme inhibition with specific antisera. J. biol. Chem. 234, 1456.

MageE, D.F. \& ANDERSON, E.G. (1955) Changes in pancreatic enzymes brought about by alteration in the nature of dietary protein. Amer. J. Physiol. 181, 79.

MiXter, C.G., Keynes, W.M. \& Cope, O. (1962) Further experience with pancreatitis as a diagnostic clue to hyperparathyroidism. New Engl. J. Med. 266, 265.

Myers, V.C., Free, A.H. \& Rosinski, E.E. (1944) Studies on animal diastase. VI. The determination of diastase (amylase) in blood. J. biol. Chem. 154, 39.

Peters, N., Dick, A.P., Hales, C.N., OrRell, D.H. \& SARNER, M. (1966) Exocrine and endocrine pancreatic function in diabetes mellitus and chronic pancreatitis. Gut, 7, 277.

Sarda, L. \& Desnuelle, P. (1958) Action de la lipase pancreatique sur les esters en emulsion. Biochim. biophys. Acta (Amst.), 30, 513.

Sarles, H., Jodrani-Oswald, G. \& Sarles, J.C. (1958) Valeur diagnostique de l'activite lipasique maxima du suc duodenal recueilli par tubage sans injection de secretine. Arch. Mal. Appar. dig. 47, 261.

Sarles, H., Sarles, J-C., Camatte, R., Muratore, R., Gaini, M., Guien, C., Pastor, J. \& le Roy, F. (1965) Observations on 205 confirmed cases of acute pancreatitis, recurring pancreatitis and chronic pancreatitis. Gut, 6, 545 .

Somogy, M. (1938) Micromethods for the estimation of diastase. J. biol. Chem. 125, 399.

Sun, D.C.H. \& SHAY, H. (1960) Pancreozymin-secretin test. Gastroenterology, 38, 570.

TietZ, N.W., Borsem, T. \& Stepleton, J.D. (1959) An improved method for the determination of lipase in serum. Amer. J. clin. Path. 31, 148.

Ujihira, I., Searcy, R.L., Berk, J.E. \& Hayashi, S. (1965) A saccharogenic method for estimating electrophoretic and chromatographic distribution of human serum amylase. Clin. Chem. 11, 97.

Ventzke, L.E., Davidson, W.A. \& Grossman, M.I. (1964) Diagnostic value of pancreatic enzymatic response to a test meal. Gastroenterology, 46, 765.

WEBBER, H. (1965) Mickromethode zur Bestimmung der Pankreaslipase im Serum. Dtsch. med. Wschr. 90, 1170.

Wilding, P., Cooke, W.T. \& Nicholson, G.I. (1964) Globulin-bound amylase. Ann. intern. Med. 60, 1053.

Young, N.F. (1953) Standard Methods of Clinical Chemistry (Ed. by M. Reiner). Academic Press, New York. 